\title{
A Multiplex Housing Energy Conservation Strategy through Combining Insulation Standard Based Green Roof Systems and Passive Design Elements
}

\author{
Son, Hyeongmin*
}

Park, Dong Yoon**

Chang, Seongju $u^{\star \star \star}$

\begin{abstract}
Recently, the coverage of urban forests has been rapidly decreasing as the cities are created and expanding Consequently, there arise urban problems such as heat island effect, urban flooding, urban desertification and so on. In this context, green roof systems is considered to be an efficient alternative to deal with these problems. However, it is difficult to apply green roof to new buildings since the majority of the buildings in cities are already constructed and the demand for new building constructions is not high enough. Therefore, it should be considered to apply green roof system to existing buildings for resolving various problems. This study evaluates heating and cooling energy consumption based on the combination of passive design factors such as wall, roof, window insulation in addition to a green roof system applied to an existing house by using an energy simulation program. Total 8 potential improvement cases are developed. Each case is applied to the same house with different insulation standard for simulations.

Through the analysis of the simulated cases with the chosen test house, it is confirmed that heating energy consumption decreases as improvement cases are applied, but cooling energy consumption is relatively not much affected by each improvement case. In addition, when each improvement case is applied to already highly insulated house, the effect of thermal energy improvement decreases while the same improvement that is applied to the case with low insulated house tends to yield higher improvement rate.
\end{abstract}

Keywords : Green roof, Passive elements, Insulation standard, Cooling heating energy consumption, Simulation

\section{Introduction}

\subsection{Background and Purpose of the Study}

The rapid expansion of urban population has led to the heat island effect, urban flooding, depletion of the ground water, and urban desertification, etc, to cause significant changes in the environment of the cities [1]. In addition, expansion of the cities resulted in contracting of the green areas in the city, which not only degrades the quality of life of the citizens but also increases the thermal load on the city. However, it is very difficult to disperse the once-concentrated population of the cities, and it is still more difficult to secure green areas in an already-developed area. One of the alternatives that could be used to solve these problems is the green roof system, which is being actively studied nowadays. Various

* Dept. of Civil and Environmental Engineering, KAIST, South Korea(nemilhm@kaist.ac.kr)

** Dept. of Civil and Environmental Engineering, KAIST, South Korea(dypark@kaist.ac.kr)

*** Corresponding author, Dept. of Civil and Environmental Engineering, KAIST, South Korea (schang@kaist.ac.kr) advantages of the green roof system includes reduction of the loss of the rain water, mitigation of the heat island effect, reducing the energy consumption of the building, providing a place of refreshment, and improving the quality of the air and the water [2]. Also transpiration and photo-synthesis consume the solar energy, contributing to a lower ambient temperature around the building. The shade of the greens also reduces the amount of sunlight heating the building, resulting in further reduced temperature of the surface of the building [3]. As such, green roof system may provide some positive effects for reducing energy consumption of a building.

Many different disciplines, as result, enthusiastically proceed with studies on this technology. Taekyoung Ahn (2003) illustrated that green roofing had an actual effect on conservation of heating energy consumption by decreasing the temperature of the top floor [4]. Taehoon Hong (2012) added some passive elements to the green roof system and examined the energy saving effect in an educational facility from adding green roof systems for each region [5]. Jongmin Kim (2009) analyzed the energy saving effect for cooling and heating by adding green roofs for different regions in the country [6]. Donghceol 
Yoo (2011) examined the energy saving effect and enhancement of PV panel efficiency through integrating the PV system and green roofing [7]. As such, there have been a number of development and study attempts in Korea. However, the level of utilizing green roof technology is still in its earliest stage. This is because many of the buildings build in the past were completed without any considerations for green roofing and the number of new building where the green roofing system can be applied is not significant.

Therefore, in this study, we conducted comparative analysis on the energy saving effect based on the existing heat insulation criteria from green roofing as a remodeling element and the passive insulation elements were combined, with a view to examine an effective green roof application method.

\subsection{Research Process and Methods}

The purpose of this study is to identity the environmentfriendly remodeling elements in a multiplex housing environment and combine them with green roof system to examine the energy saving effect from green roofing. For this reason, we referred to 'The survey on the resident's consciousness regarding environment-friendly remodeling of the apartment housing' to identify the remodeling elements [8]. The remodeling elements referred to include the reinforcement of insulation on the outer and main wall, reinforcement of heat insulation of the roof, improvement of tightness and heat insulation performance of the front door and windows, use of high efficiency/energy saving type appliances, use of the solar energy, and use of equipment that can utilize unused energy. Of these elements the passive ones included the reinforcement of insulation on the outer and main wall, reinforcement of heat insulation of the roof, and improvement of tightness and heat insulation performance of the front door and windows. These elements were applied to simulations in combination with green roofs. The passive element's attributes were set based on the heat insulation standard in effect in 2010. The basic green roofing configurations and the 3 selected elements of roof insulation, wall insulation, and window insulation were combined in 8 different cases, which were used for the simulation. The details of the combination cases used for this study are as shown in Table 1. In this study, we analyzed the correlations between green roofing and other passive elements through the analysis of the energy consumption in cooling and heating. Also, each of the simulation scenario cases were applied to the same building where the insulation criteria of 1987 and 2001, when the insulation standard was changed, to identify the effectiveness of each case in different insulation standard scenarios. The insulation standard that were in effect in 1987, 2001, and 2010 are as shown in Table 2. And, Fig. 1 shows the study overview and methods.

Table 1. List of 8 Cases by the combinations with GRS

\begin{tabular}{ll}
\hline Case number & Combination \\
\hline Case $* 1$ & GRS \\
Case $* 2$ & GRS $+* 1$ \\
Case $* 3$ & GRS $+* 2$ \\
Case $* 4$ & GRS $+* 3$ \\
Case $* 5$ & GRS $+* 1+* 2$ \\
Case $* 6$ & GRS $+* 1+* 3$ \\
Case $* 7$ & GRS $+* 2+* 3$ \\
Case $* 8$ & GRS $+* 1+* 2+* 3$ \\
\hline GRS : Green Roof System & $* 1:$ roof insulation $* 2:$ window insulation \\
$* 3:$ wall insulation &
\end{tabular}

Table 2. Revised insulation standards

\begin{tabular}{|c|c|c|c|c|c|c|}
\hline \multirow[b]{2}{*}{$\begin{array}{l}\text { Revision } \\
\text { time }\end{array}$} & \multirow[b]{2}{*}{ District } & \multicolumn{5}{|c|}{ Insulation Standard $\left(\mathrm{U}\right.$-value : $\left.\mathrm{W} / \mathrm{m}^{2} \cdot \mathrm{K}\right)$} \\
\hline & & $\begin{array}{l}\text { Ext. } \\
\text { wall }\end{array}$ & $\begin{array}{l}\text { Under } \\
\text { floor }\end{array}$ & Roof & $\begin{array}{l}\text { Multi-unit } \\
\text { dwelling } \\
\text { sidewall }\end{array}$ & $\begin{array}{c}\text { Window } \\
\text { meet } \\
\text { outside }\end{array}$ \\
\hline 1987.07 & \multirow{3}{*}{$\begin{array}{l}\text { Cental } \\
\text { district }\end{array}$} & 0.5813 & 0.5813 & 0.407 & 0.465 & 3.37 \\
\hline 2001.01 & & 0.47 & 0.58 & 0.29 & 0.35 & 3.84 \\
\hline 2010.11 & & 0.36 & 0.58 & 0.2 & 0.27 & 2.1 \\
\hline
\end{tabular}

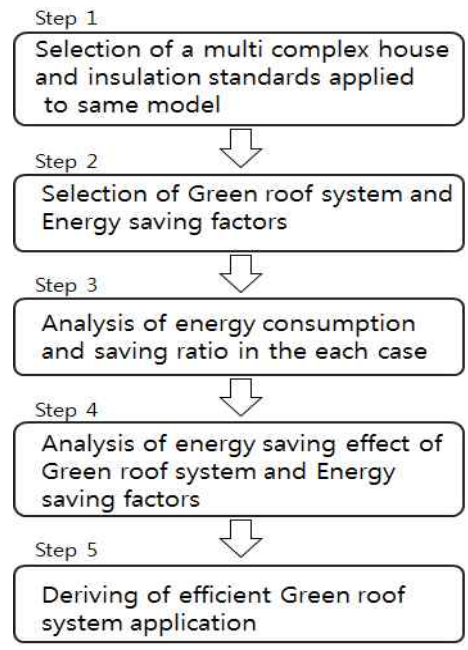

Fig 1. Research Framework

\section{Study Objects and Simulation Scenarios}

The simulation was conducted using Design Builder 3.0, which was based on Energy Plus.

\subsection{Target Building}

The target building for this simulation was a building 
of 1 basement and 4 stories that was located in Hongdo -dong, Seoul. All of the floors above the ground were used for residential purposes. The heating system was under floor heating type, and cooling system as of an individual air-conditioning type. In the simulation, we analyzed the 4 th floor which could be affected by the application of green roofing. The residential units on the 4th floor were zoned into Domestic Bedrooms and Domestic Lounges, Circulation Area such as entrance. Staircase, Terrace were classified as None. Fig. 2 shows the zoning of the units that was used for the simulation. The volume, floor area, the area of the outer wall and windows are as shown in Table 3. We used the blueprint of the target building to obtain the detailed data on the building and modeled the building for simulation using Design Builder. The green roofing elements used by Design Builder were those shown in Fig. 3. The elements included the sensible heat flux $\left(\mathrm{H}_{\mathrm{f}}\right)$ of the leaves, latent heat of the soil $\left(\mathrm{L}_{\mathrm{g}}\right)$, latent heat of the leaves $\left(\mathrm{L}_{\mathrm{f}}\right)$, sensible heat flux of the soil $\left(\mathrm{H}_{\mathrm{g}}\right)$, total amount of incoming shortwave radiation $\left(I_{S}\right)$, total amount of incoming long wave radiation $\left(\mathrm{I}_{\mathrm{ir}}\right)$, albedo of the leaves $\left(\mathrm{a}_{\mathrm{f}}\right)$, albedo of the surface of the soil $\left(a_{g}\right)$, the temperature of the soil surface $\left(\mathrm{T}_{\mathrm{g}}\right)$, surface radiation on the soil $(\varepsilon$ g), and long wave radiation beneath the leaves (LW) [9].

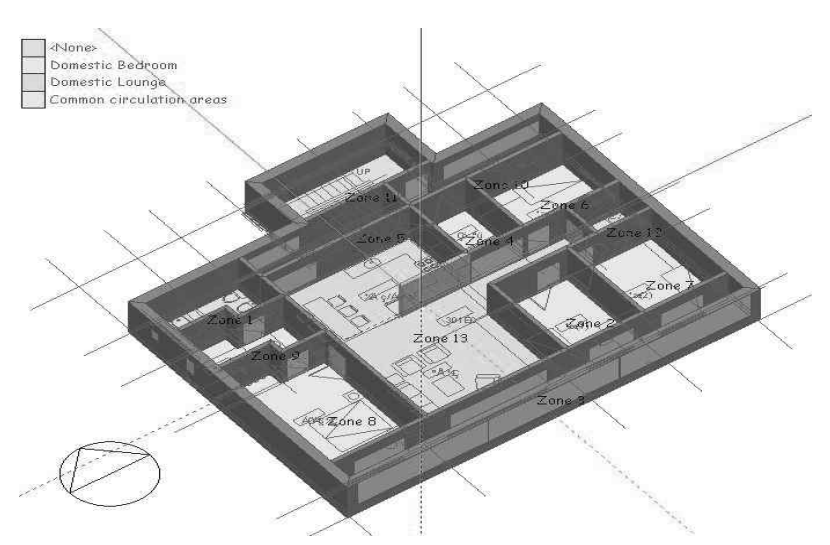

Fig 2. Target housing unit model for simulations

Table 3. Zonning of the simulation target house

\begin{tabular}{c|c|c|c|c}
\hline Zone & $\begin{array}{c}\text { Domestic } \\
\text { bedroom }\end{array}$ & $\begin{array}{c}\text { Domestic } \\
\text { lounge }\end{array}$ & $\begin{array}{c}\text { Circulation } \\
\text { area }\end{array}$ & None \\
\hline volume $\left(\mathrm{m}^{3}\right)$ & 158.22 & 153.77 & 40.90 & 140.75 \\
\hline floor area $\left(\mathrm{m}^{2}\right)$ & 56.51 & 54.92 & 14.61 & 50.27 \\
\hline ext.wall area $\left(\mathrm{m}^{2}\right)$ & 35.84 & 0 & 6.16 & 56.27 \\
\hline window area $\left(\mathrm{m}^{2}\right)$ & 10.92 & 15.83 & 1.1 & 33.64 \\
\hline
\end{tabular}

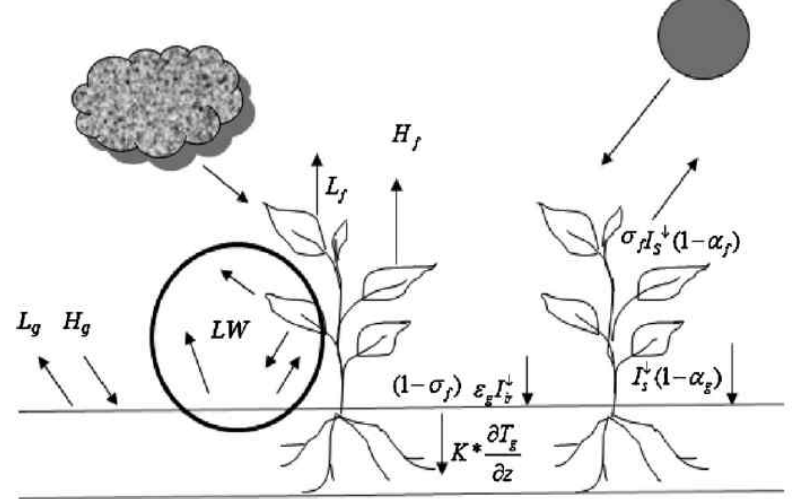

Fig 3. Green roof energy balance model [10]

\subsection{Settings for the Simulation}

The physical properties of the construction elements of the target buildings were designed differently in accordance with the insulation standard in effect for different years in the scenario. Based on the years when the standard saw changes, the physical characteristics of the outer wall and the roof heat insulation for the year 1987, 2001, and 2010 were as shown in Table 4. The heat insulators were of internal insulation types. The thermal bridge effect of the interfaces between the materials was not considered in this simulation. The physical characteristics of the window insulation were as shown in Table 5. The physical properties of the green roofing elements were the same ones used in the studies by Taehoon Hong, Jimin Kim, and Choongwan Koo, which were as shown in Table 6 [11]. However, the thickness of the soil layer was set to $300 \mathrm{~mm}$, which was proven in the preceding studies to be of the high insulation performance without any structural load problem to the target building [12].

The weather data was based on the standard weather data provided by Korea Sola Energy Association. The temperature of heating was set to $21^{\circ} \mathrm{C}, 26^{\circ} \mathrm{C}$ for the temperature of cooling, based on the recommended cooling and heating temperature in effect in Korea. The number of occupants in the rooms were 5 based on the simulated area, which made the number of persons per unit area $0.05 / \mathrm{m}^{2}$. Further details in each of the zones set for the simulation were as shown in Table 7 . 
A Multiplex Housing Energy Conservation Strategy through Combining Insulation Standard Based Green Roof Systems and Passive Design Elements / Son, Hyeongmin.Park, Dong

Table 4. Properties of the materials

\begin{tabular}{|c|c|c|c|c|}
\hline \multicolumn{5}{|c|}{1987 Properties of the materials } \\
\hline & Material & $\begin{array}{l}\text { Thickness } \\
{[\mathrm{mm}]}\end{array}$ & $\begin{array}{l}\text { Conductivity } \\
{[\mathrm{W} / \mathrm{mK}]}\end{array}$ & $\begin{array}{l}\text { Specific } \\
\text { heat } \\
{[\mathrm{J} / \mathrm{kg} \cdot \mathrm{K}]}\end{array}$ \\
\hline \multirow{3}{*}{$\begin{array}{l}\text { Ext } \\
\text { wall }\end{array}$} & $\begin{array}{l}\text { concrete reinforced } \\
\text { (with } 2 \% \text { steel) }\end{array}$ & 220 & 2.5 & 1000 \\
\hline & glass fibre wool & 50 & 0.040 & 840 \\
\hline & gypsum board & 60 & 0.25 & 1000 \\
\hline \multirow{6}{*}{ Roof } & $\begin{array}{l}\text { concrete roofing } \\
\text { slab }\end{array}$ & 50 & 0.16 & 840 \\
\hline & roofing felt & 4 & 0.19 & 837 \\
\hline & Foam-polyurethan & 50 & 0.03 & 1470 \\
\hline & Asphalt-poured & 1 & 1.2 & 920 \\
\hline & $\begin{array}{l}\text { concrete reinforced } \\
\text { (with } 2 \% \text { steel) }\end{array}$ & 200 & 2.5 & 1000 \\
\hline & $\begin{array}{l}\text { Gypsum plaster } \\
\text { board }\end{array}$ & 80 & 0.25 & 1000 \\
\hline \multicolumn{5}{|c|}{2001 Properties of the materials } \\
\hline & Material & $\begin{array}{l}\text { Thickness } \\
{[\mathrm{mm}]}\end{array}$ & $\begin{array}{l}\text { Conductivity } \\
{[\mathrm{W} / \mathrm{mK}]}\end{array}$ & $\begin{array}{l}\text { Specific } \\
\text { heat } \\
{[\mathrm{J} / \mathrm{kg} \cdot \mathrm{K}]}\end{array}$ \\
\hline \multirow{3}{*}{$\begin{array}{l}\text { Ext } \\
\text { wall }\end{array}$} & $\begin{array}{l}\text { concrete reinforced } \\
\text { (with } 2 \% \text { steel) }\end{array}$ & 220 & 2.5 & 1000 \\
\hline & glass fiber wool & 100 & 0.040 & 840 \\
\hline & gypsum board & 80 & 0.25 & 1000 \\
\hline \multirow{6}{*}{ Roof } & $\begin{array}{l}\text { concrete roofing } \\
\text { slab }\end{array}$ & 50 & 0.16 & 840 \\
\hline & roofing felt & 4 & 0.19 & 837 \\
\hline & Foam-polyurethan & 80 & 0.03 & 1470 \\
\hline & Asphalt-poured & 1 & 1.2 & 920 \\
\hline & $\begin{array}{l}\text { concrete reinforced } \\
\text { (with } 2 \% \text { steel) }\end{array}$ & 200 & 2.5 & 1000 \\
\hline & $\begin{array}{l}\text { Gypsum plaster } \\
\text { board }\end{array}$ & 80 & 0.25 & 1000 \\
\hline \multicolumn{5}{|c|}{2010 Properties of the materials } \\
\hline & Material & $\begin{array}{l}\text { Thickness } \\
{[\mathrm{mm}]}\end{array}$ & $\begin{array}{l}\text { Conductivity } \\
{[\mathrm{W} / \mathrm{mK}]}\end{array}$ & $\begin{array}{l}\text { Specific } \\
\text { heat } \\
{[\mathrm{J} / \mathrm{kg} \cdot \mathrm{K}]}\end{array}$ \\
\hline \multirow{3}{*}{$\begin{array}{l}\text { Ext } \\
\text { wall }\end{array}$} & $\begin{array}{l}\text { concrete reinforced } \\
\text { (with } 2 \% \text { steel) }\end{array}$ & 220 & 2.5 & 1000 \\
\hline & $\begin{array}{l}\text { XPS Extruded } \\
\text { Polystyrene - } \mathrm{CO} 2 \\
\text { Blow }\end{array}$ & 110 & 0.034 & 1400 \\
\hline & gypsum board & 80 & 0.25 & 1000 \\
\hline \multirow{6}{*}{ Roof } & $\begin{array}{l}\text { concrete roofing } \\
\text { slab }\end{array}$ & 50 & 0.16 & 840 \\
\hline & roofing felt & 4 & 0.19 & 837 \\
\hline & $\begin{array}{l}\text { XPS Extruded } \\
\text { Polystyrene - CO2 } \\
\text { Blow }\end{array}$ & 140 & 0.034 & 1400 \\
\hline & Asphalt-poured & 1 & 1.2 & 920 \\
\hline & $\begin{array}{l}\text { concrete reinforced } \\
\text { (with } 2 \% \text { steel) }\end{array}$ & 200 & 2.5 & 1000 \\
\hline & $\begin{array}{l}\text { Gypsum plaster } \\
\text { board }\end{array}$ & 100 & 0.25 & 1000 \\
\hline
\end{tabular}

\section{Energy Simulation Analysis of the Target Building}

Table 8 shows the heating and cooling energy consumption level when the green roofing and other passive elements were deducted from the simulation based
Table 5. Properties of the window

\begin{tabular}{c|l|c|c|c}
\hline & Material & $\begin{array}{l}\text { Thickness } \\
{[\mathrm{mm}]}\end{array}$ & $\begin{array}{l}\text { Air gap } \\
{[\mathrm{mm}]}\end{array}$ & $\begin{array}{l}\mathrm{U}-\mathrm{value} \\
{\left[\mathrm{W} / \mathrm{m}^{2} \cdot \mathrm{K}\right]}\end{array}$ \\
\hline 1987 & $\begin{array}{l}\text { Generic } \\
\text { LOWIRON }\end{array}$ & 3 & 6 & 3.159 \\
\hline 2001 & $\begin{array}{l}\text { Generic } \\
\text { LOWIRON }\end{array}$ & 5 & 6 & 3.115 \\
\hline 2010 & $\begin{array}{l}\text { Generic } \\
\text { PYR B } \\
\text { CLEAR }\end{array}$ & 3 & 13 & 1.960 \\
\hline
\end{tabular}

Table 6. Properties of the green roof systems

\begin{tabular}{|c|c|c|c|}
\hline Leaf & $\begin{array}{l}\text { Grass and } \\
\text { flower }\end{array}$ & Soil type & $\begin{array}{l}\text { Natural } \\
\text { soil }\end{array}$ \\
\hline Height of plant (m) & 0.15 & Thickness (m) & 0.3 \\
\hline Leaf area index & 2.5 & $\begin{array}{l}\text { Conductivity of } \\
\text { dry soil } \\
(\mathrm{W} / \mathrm{m}-\mathrm{K})\end{array}$ & 0.5 \\
\hline Leaf reflectivity & 0.1 & $\begin{array}{l}\text { Specific heat } \\
(\mathrm{J} / \mathrm{kg}-\mathrm{K})\end{array}$ & 1350 \\
\hline Leaf emissivity & 0.8 & $\begin{array}{l}\text { Density of dry } \\
\text { soil } \\
(\mathrm{kg} / \mathrm{m} 3)\end{array}$ & 800 \\
\hline $\begin{array}{l}\text { Minimum stomatal } \\
\text { resistance }(\mathrm{s} / \mathrm{m})\end{array}$ & 180 & $\begin{array}{l}\text { Thermal } \\
\text { absorptance } \\
\text { (emissivity) }\end{array}$ & 0.9 \\
\hline $\begin{array}{l}\text { Max volumetric moisture } \\
\text { content at saturation }\end{array}$ & 0.5 & $\begin{array}{l}\text { Solar } \\
\text { absorptance }\end{array}$ & 0.6 \\
\hline $\begin{array}{l}\text { Min residual volumetric } \\
\text { moisture content }\end{array}$ & 0.01 & $\begin{array}{l}\text { Visible } \\
\text { absorptance }\end{array}$ & 0.6 \\
\hline $\begin{array}{l}\text { Initial volumetric moisture } \\
\text { content }\end{array}$ & 0.15 & - & - \\
\hline
\end{tabular}

Table 7. Conditions for the simulations

Conditions for the simulation target house model

\begin{tabular}{l|l}
\hline Weather data & $\begin{array}{l}\text { Climate data in Incheon, Which is } \\
\text { similar to Seoul }\end{array}$ \\
\hline Run period & $01 / 01 / 2010 \sim 12 / 31 / 2010$ \\
\hline Holiday & Korea, 2010 \\
\hline Schedule & Dwell \\
\hline Occupancy & $0.05\left(\right.$ people $\left./ \mathrm{m}^{2}\right)$ \\
\hline Equipment & $3.9 \mathrm{~W} / \mathrm{m}^{2}$ \\
\hline Lighting load density & $5 \mathrm{~W} / \mathrm{m}^{2}$ \\
\hline Natural Ventilation & $2-\mathrm{Min}$ fresh air $($ Per person) \\
\hline Setting temperature & $\begin{array}{l}\text { Heating set point: } 21^{\circ} \mathrm{C} \\
\text { Cooling set point: } 26^{\circ} \mathrm{C}\end{array}$ \\
\hline
\end{tabular}

on the settings in accordance with the insulation requirements of 1987 . In this scenario, $22648.35 \mathrm{kWh}$ was consumed for heating, while $1881.18 \mathrm{kWh}$ was used in cooling. Table 9 shows the heating energy consumption and the reduction rate in each of the 
analysis case for the target building (green roofing, roof, wall, and windows insulation) based on the heat insulation standard of 1987 . When the insulation standard of 1987 was applied to case 8, $11702.94 \mathrm{kWh}$ was consumed in heating, which was a $48.32 \%$ reduction of heat energy usage. For case 1, where only the green roofing was applied, $20049.63 \mathrm{kWh}$ of energy was consumed, with a heating energy saving rate of $11.47 \%$. In case 6 , where the green roofing and insulation reinforcement of the roof and the outer walls were applied, the heating energy consumption was reduced by $40.73 \%$. In the meantime, in case 7 , where the green roofing and insulation reinforcement of the windows and the outer walls were applied, the heating energy consumption was reduced by $33.36 \%$. The difference in energy saving rate between case 6 and 7 is thought to be resulting from strengthening of the requirements in the insulation standard for the roof and the outer wall since 2010 compared to those in effect in 1987, as well as the wider area of these elements. In case 2, where the roof insulation reinforcement was applied in conjunction with the green roofing, the energy saving rate was $25.73 \%$, which was higher by $14.26 \%$ compared to case 1 , where only the green roofing was applied. This shows that green roofing alone cannot be sufficient to obtain the desired level of heat insulation on the roof, and it is required to use the passive insulation of the roof in conjunction with it to increase the heat insulation efficacy.

Table 8. Heating and cooling energy consumption with standard insulations

\begin{tabular}{c|c|c}
\hline Insulation standard & $\begin{array}{c}\text { Heating energy } \\
\text { consumption }(\mathrm{kWh})\end{array}$ & $\begin{array}{c}\text { Cooling energy } \\
\text { consumption (kWh) }\end{array}$ \\
\hline 1987 standard & 22648.35 & 1881.18 \\
\hline 2001 standard & 17482.40 & 1911.73 \\
\hline
\end{tabular}

In Table 10, the cooling energy consumption and the reduction rate for each case based on the heat insulation standard of 1987 are summarized. As for the energy saving rate for cooling in case 1 , where green roofing is applied, $3.11 \%$ of cooling energy saving rate is obtained. This is thought to be resulting from the reduction of the surface temperature as the water contained in the soil takes heat away as it evaporates, in addition to the LAI (Leaf Area Index) effect due to the shading by the leaves when green roofing is applied. Case 8, where green roofing and insulation of the roof, wall, and windows were applied, showed an cooling energy saving rate of $-2.27 \%$, meaning the consumption
Table 9. Heating energy consumption and energy saving rate

\begin{tabular}{c|c|c}
\hline Type & $\begin{array}{c}\text { 1987 Heating energy } \\
\text { consumption }(\mathrm{kWh})\end{array}$ & $\begin{array}{c}\text { 1987 Heating energy } \\
\text { saving rate }(\%)\end{array}$ \\
\hline Case 1 & 20049.63 & 11.47 \\
\hline Case 2 & 16820.26 & 25.73 \\
\hline Case 3 & 18579.89 & 17.96 \\
\hline Case 4 & 16734.25 & 26.11 \\
\hline Case 5 & 15279.46 & 32.53 \\
\hline Case 6 & 13423.28 & 40.73 \\
\hline Case 7 & 15092.02 & 33.36 \\
\hline Case 8 & 11702.94 & 48.32 \\
\hline
\end{tabular}

Table 10. Cooling Energy consumption and energy saving rate

\begin{tabular}{c|c|c}
\hline Type & $\begin{array}{c}\text { 1987 Cooling Energy } \\
\text { consumption }(\mathrm{kWh})\end{array}$ & $\begin{array}{c}\text { 1987 Cooling Energy } \\
\text { saving rate }(\%)\end{array}$ \\
\hline Case 1 & 1822.64 & 3.11 \\
\hline Case 2 & 1859.57 & 1.14 \\
\hline Case 3 & 1810.25 & 3.77 \\
\hline Case 4 & 1868.36 & 0.68 \\
\hline Case 5 & 1852.25 & 1.53 \\
\hline Case 6 & 1916.48 & -1.87 \\
\hline Case 7 & 1864.51 & 0.88 \\
\hline Case 8 & 1923.93 & -2.27 \\
\hline
\end{tabular}

of energy increased. We believe the reason for this is that the heat generated by the occupants and the appliances in the room could not escape to the outside, as the insulation was fortified. In case of the building where the insulation standard of 1987 was applied, it was shown that the application of green roofing and other elements in different cases contributed more to the energy saving effect in heating than they did with cooling. That is, while the energy saving rate for cooling was between $-2.27 \%$ and $3.11 \%$, the saving rate for heating ranged from $11.47 \%$ to $48.32 \%$.

Table 11 shows the energy saving rate for heating under different case scenarios based on 2001 heat insulation standard. Table 8 shows the heating and cooling energy consumption level when the green roofing and other passive elements were deducted from the simulation based on the settings in accordance with the insulation requirements of 2001. In this scenario, $17482.40 \mathrm{kWh}$ was consumed for heating, while 1911.73 kWh was used in cooling. Case 8, where the green roofing, as well as other passive elements of the roof, wall, and windows insulation were applied, consumed $11702.94 \mathrm{kWh}$, with a heating energy saving rate of $33.05 \%$. In the meantime, case 1 , where on the green roofing was applied, the energy saving rate for heating was $10.37 \%$. The result of the study showed that as more insulation elements were added, the energy consumption for heating decreased. 
Table 12 shows the energy saving rate for cooling under different case scenarios based on 2001 heat insulation standard. The cooling energy saving rate with green roofing was $2.22 \%$. In case 8 , however, where all of the insulation elements were applied, the energy saving rate for cooling was $-0.63 \%$. We believe this is because the heat generated from inside by the occupants or the home appliances in the room fails to escape to outside. It signifies that fact that the energy consumption in cooling is not proportionate to the application of the insulating elements of each case.

When green roofing was applied to the buildings with 1987 insulation standard and 2001 insulation standard, the energy saving rate decreased in the building with 2001 standard, as the later standard was more demanding. While the energy saving rate for the building where the 1987 standard was applied was $11.47 \%$, the buildings with 2001 standard showed a $10.37 \%$ reduction of energy consumption.

Table 11. Heating energy consumption and energy saving rate

\begin{tabular}{c|c|c}
\hline Type & $\begin{array}{c}\text { 2001 Heating energy } \\
\text { consumption }(\mathrm{kWh})\end{array}$ & $\begin{array}{c}\text { 2001 Heating energy } \\
\text { saving rate }(\%)\end{array}$ \\
\hline Case 1 & 15669.36 & 10.37 \\
\hline Case 2 & 14343.66 & 17.95 \\
\hline Case 3 & 13981.61 & 20.02 \\
\hline Case 4 & 14775.07 & 15.48 \\
\hline Case 5 & 12633.87 & 27.73 \\
\hline Case 6 & 13447.68 & 23.07 \\
\hline Case 7 & 13040.36 & 25.40 \\
\hline Case 8 & 11702.94 & 33.05 \\
\hline
\end{tabular}

Table 12. Cooling energy consumption and energy saving rate

\begin{tabular}{c|c|c}
\hline Type & $\begin{array}{c}\text { 2001 Cooling energy } \\
\text { consumption }(\mathrm{kWh})\end{array}$ & $\begin{array}{c}\text { 2001 Cooling energy } \\
\text { saving rate }(\%)\end{array}$ \\
\hline Case 1 & 1869.25 & 2.22 \\
\hline Case 2 & 1890.76 & 1.09 \\
\hline Case 3 & 1882.49 & 1.52 \\
\hline Case 4 & 1880.77 & 1.61 \\
\hline Case 5 & 1908.42 & 0.17 \\
\hline Case 6 & 1902.99 & 0.45 \\
\hline Case 7 & 1895.96 & 0.82 \\
\hline Case 8 & 1923.93 & -0.63 \\
\hline
\end{tabular}

Fig. 4 shows the heating energy consumption for each case based on the insulation standard. From this, we can see that the stronger the insulation requirements become, the lower the energy reduction effect gets. That is, the energy saving effect was higher in the cases based on the heat insulation standard of 1987 than those based on the 2001 standard. This shows that the green roofing can increase the greening effect of the rooftops more in case the existing insulation capacity is

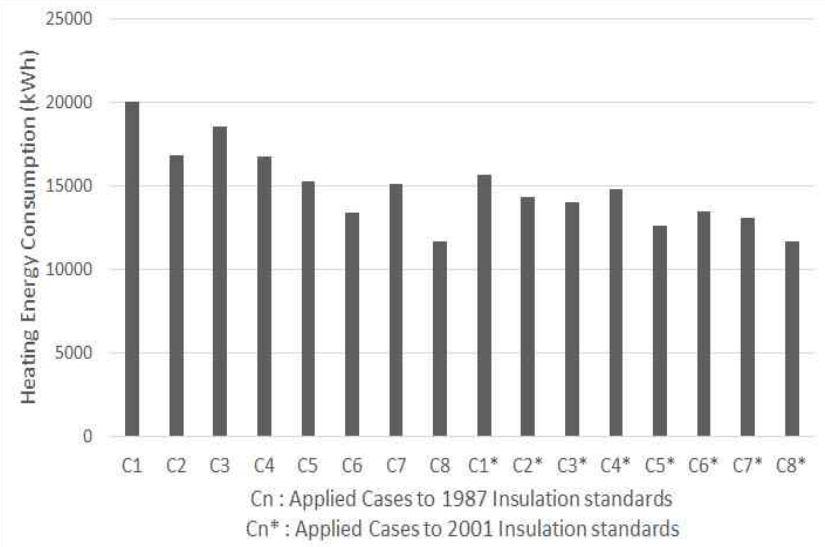

Fig 4. Heating energy consumption profiles of the test cases

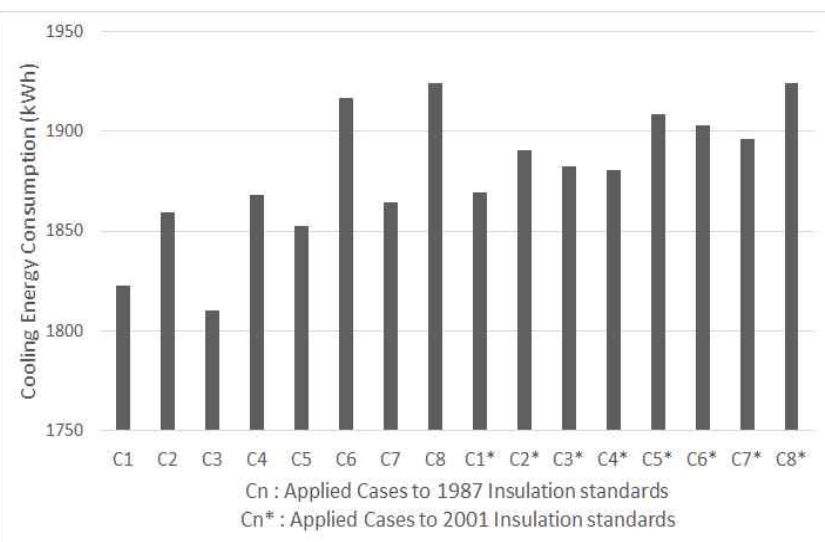

Fig 5. Cooling energy consumption profiles of the test cases

low rather than the cases with more effective insulation performance.

Fig 5. shows the cooling energy consumption based on the insulation standards. As for the cooling energy consumption, the consumption was higher under the 2001 standard than it was under the 1987 standard. When case 8 scenario was applied to 1987 and 2001 standards, the energy saving rate increased from $-2.22 \%$ to $-0.63 \%$. In case 1 , where only the green roofing was applied, the increased in insulation performance resulted in cooling energy saving rate decreasing from $3.11 \%$ to $2.22 \%$. That is, the energy consumption in cooling increased in the buildings under a more strict insulation standard. We believe this is because the heat generated from inside by the occupants or the home appliances in the room fails to escape to outside.

\section{Conclusion}

In this study, we analyzed the results of combining green roofing with other passive insulation elements in a 4 -stories building in Seoul and analyzed the energy 
saving effect under different insulation standard when green roofing was applied. The key findings from this study are as follows;

1) When green roofing was applied, $11.47 \%$ of heating energy saving rate was achieved under 1987 insulation standard, while the rate was $10.37 \%$ in the building under 2001 insulation standard. This shows that, when applying green roofing, the heating energy saving effect is higher with the buildings with lower existing insulation performance than with the ones with higher performances.

2) The application of each of the passive element had only minor contributions to the energy saving effect under cooling. When only the green roofing was applied, the shading from the plants and evaporation of the water in the soil resulted in lower energy consumption for cooling. However, when the rest of the passive insulation elements for the roof, wall, and windows were applied, the energy consumption increased. We believe this is because the heat generated from inside by the occupants or the home appliances in the room fails to escape to outside.

3) In order to achieve effective roof insulation, the green roofing should be accompanied with roof insulation. The scenario under the 1987 insulation standard saw a heating energy saving rate of $11.47 \%$ when green roofing was applied, while the rate increased to $25.73 \%$ when the green roofing was joined by roof insulation. In the meantime, the scenario under the 2001 insulation standard saw a heating energy saving rate of $10.37 \%$ when green roofing was applied, while the rate increased to $17.95 \%$ in case 2 , where the green roofing was joined by roof insulation. This indicates that green roofing alone is not sufficient for enhancing the roof insulation performance.

4) It was proven that as the insulation performance improved due to the combination between the green roofing and other passive elements, the energy consumption in heating decreased. As for cooling, it was shown that the energy saving effect decreased as the insulation performance increased, except for Case 1 where only the green roofing was applied. This is a proof that, when remodeling a multiplex house, it is more effective to use the green roofing to reduce sunlight radiation exposure and use the latent heat effect from evaporation of the water than to strengthen the heat insulation standard to reduce energy consumption.

In conclusion, we discovered that energy saving rate for heating and cooling due to application of green roofing differed depending on the existing insulation capacity of the building and the combination with other passive insulation elements. This signifies that, when applying green roofing, it is important to consider the combination with other elements as well as the existing insulation capacity of the building. Also, further studies would be welcome to examine the feasibility of green roofing based on the initial investment cost and the cost saving effect due to energy saving that were not covered in this study.

\section{Acknowledgement}

This research was supported by Architectural Design Guidelines for the Diffusion of Green Roofs from Land \& Housing Institute (LHI) and financially supported by Korea Minister of Ministry of Land, Infrastructure and Transport (MOLIT) as U-City Master and Doctor Course Grant Program.

\section{References}

[1] V.Heffernan, Roof and the Environment, Canadian Consulting Engineer, 2003

[2] Lisa Kosareo, Robert Ries, Comparative environmental life cycle assessment of green roofs, Builidng and Environment, 2007, Vol 42, p.2606-2613

[3] Nyuk Hien Wong, Yu Chen, Chui Leng ong, Angelic Sia, Investigation of thermal benefits of rooftop garden in the tropical environment. Building and Environment, 2003, Vol 38, p.261-270

[4] Tae-Kyung Ahn, Evaluation for thermal performance of apartment house top floor using roof planting system, Journal of the Korean society of living environmental system, 2003, Vol.10 No.3, p. $182-186$

[5] TaeHoon Hong, JiMin Kim, ChoongWan Koo, LCC and $\mathrm{LCCO}_{2}$ analysis of green roofs in elementary schools with energy saving measures, Energy and Buildings, 2012, Vol 45, p.229-239

[6] Kim, Chong-Min, A study on Energy Saving Effect for the Green Roof on Mega-City, Architectural institute of Korea, 2009, Vol 11, p.93-100

[7] Yoo, Dong-cheol, Kim, Jun-hi, Yun, doo-young, Lee, Eung-jik, A comparison of the distribution of surface temperature on the green roof vs non-green roof, The korean solar energy society, 2012, Vol.32, p.371-374 
[8] Lee Eun-young, Cung you sun, Yoon, Chung-Sook. The Surveyon the Resident's Consciousness regarding Environment-Friendly Remodeling of the Apartment Housing, Architectural institute of Korea, 2006, Vol.22, p31-38

[9] D.J Sailor, A green roof model for building energy simulation programs, Energy and Buildings, 2008, Vol 40, p.1466-1478

[10] D.J Sailor, A green roof model for building energy simulation programs, Energy and Buildings, 2008, Vol 40, p.1466-1478

[11] TaeHoon Hong, JiMin Kim, ChoongWan Koo, LCC and $\mathrm{LCCO}_{2}$ analysis of green roofs in elementary schools with energy saving measures, Energy and Buildings, 2012, Vol 45, p.229-239

[12] Kim, Chong-Min, A study on Energy Saving Effect for the Green Roof on Mega-City, Architectural institute of Korea, 2009, Vol 11, p.93-100

Received January 3, 2014;

Final revision received February 3, 2014;

Accepted February 5, 2014; 